CLINICAL STUDY

\title{
Plasma resistin levels correlate with determinants of the metabolic syndrome
}

\author{
G D Norata ${ }^{1,2}$, M Ongari $^{1}$, K Garlaschelli $^{1}$, S Raselli $^{1}$, L Grigore $^{1}$ and A L Catapano ${ }^{1,2}$ \\ ${ }^{1}$ Centro SISA per lo Studio della Aterosclerosi, Ospedale Bassini, Cinisello Balsamo, Milano, Italy and ${ }^{2}$ Department of Pharmacological Sciences, University \\ of Milan, Milano, Italy
}

(Correspondence should be addressed to G D Norata who is now at Department of Pharmacological Sciences, Via Balzaretti 9, 20100 Milano, Italy; Email: danilo.norata@unimi.it)

\begin{abstract}
Objective: The role of resistin in insulin sensitivity and obesity is controversial. Some authors suggest that increased serum resistin levels are associated with obesity, visceral fat, insulin resistance, type 2 diabetes and inflammation, while others failed to observe such correlations. The aim of the present study was to investigate the relationship of plasma resistin levels with markers of the metabolic syndrome and atherosclerosis in a large population-based study.

Design and patients: Plasma resistin levels were determined in 1090 subjects free of any medication selected from the PLIC study (designed to verify the presence of atherosclerotic lesions and progression intimamedia thickness (IMT) in the common carotid artery in the general population) and related to the presence of obesity, metabolic syndrome, metabolic abnormalities, cardiovascular risk, and progression of IMT. Results: Plasma resistin levels were highly positively correlated with triglycerides, waist circumference, waist/hip ratio, systolic blood pressure, and ApoAI/ApoB ratio, while they were inversely correlated with high density lipoprotein and ApoAI levels. This finding was gender specific (mainly in women). Plasma resistin levels were significantly higher in women with the metabolic syndrome compared with controls (4.90 (0.24) ng/ml vs $3.90(0.11) \mathrm{ng} / \mathrm{ml} ; \mathrm{P}<0.01)$, while no difference was observed in obese subjects. Finally, plasma resistin levels were significantly correlated with cardiovascular risk calculated according to the Framingham algorithm $(P<0.01)$.

Conclusion: Plasma resistin levels are increased in presence of the metabolic syndrome and are associated with increased cardiovascular risk.
\end{abstract}

European Journal of Endocrinology 156 279-284

\section{Introduction}

Resistin is a $10 \mathrm{kDa}$ protein of 94 amino acids, which belongs to the resistin-like molecules family and was cloned in 2001 as a thiazolidinediones (TZD)-regulated cytokine expressed in adipose tissue (1-3). Its effects on insulin action have been extensively investigated in mice (4-10), where resistin is involved in hepatic glucose and lipid metabolism $(7,11)$ and appears to be a major determinant of hepatic insulin resistance induced by high-fat diet (12). Subsequent studies in rodents have suggested resistin as a link between obesity, insulin resistance, and diabetes (13-15). In humans, data on the role of this adipokine in insulin sensitivity and obesity are controversial (16). Some authors indicated that increased serum resistin levels are associated with increased obesity, visceral fat $(4,17,18)$, insulin resistance, and type 2 diabetes $(19,20)$, while other groups failed to observe such correlations (20-23). Savage et al. have shown that resistin mRNA expression is high in circulating mononuclear cells, while it is low in adipocytes and almost undetectable in preadipocytes, endothelial cells, and smooth muscle cells (24); thus suggesting the possibility that different sources of resistin could be responsible for the different effects observed in mice and humans. Furthermore, the contribution of resistin to the metabolic syndrome and cardiovascular disease is still under investigation $(25,26)$.

The aim of the present study was thus to investigate the relation of plasma resistin levels with markers of the metabolic syndrome and atherosclerosis in a large population-based study.

\section{Materials and methods}

\section{Study design}

We studied 2141 subjects recruited from the progressione lesione intimale carotidea (PLIC) study, designed to verify the presence and progression of atherosclerotic lesions and intima-media thickness (IMT) in the common carotid artery, and how IMT relates to major 
risk factors for cardiovascular diseases, such as plasma lipids, lifestyle habits, blood pressure, and other new markers of atherosclerosis. The subjects signed an informed consent, and this study was approved by the Ethics Committee of the Centre and conducted under the principles of the Declaration of Helsinki. The clinical outcome measures, such as triglycerides, high density lipoprotein cholesterol (HDL-C), low density lipoprotein cholesterol (LDL-C), total cholesterol, systolic and diastolic blood pressure (SBP and DBP), body-mass index (BMI), waist/hip ratio, and cardiovascular risk calculated according to the Framingham algorithm (RCV), were obtained as previously described $(27,28)$. Glucose was measured using the Trinder enzymatic assay and the Cobas Mira Plus analyser (Horiba, Montpellier, ABX, France), while ApoAI and ApoB were measured following turbidimetric analysis and processing in the Cobas Mira Plus analyser. Data on insulin plasma levels and homeostasis model assessment (HOMA) are available from 300 randomly selected subjects. IMT was evaluated in all subjects at the beginning of the study $\left(\mathrm{IMT}_{0}\right)$ and after 2 years of follow-up (27) and data are presented as IMT progression $(\Delta \mathrm{IMT})$. To avoid any confounding effect due to pharmacological treatment, among the subjects enrolled in the PLIC study, we excluded 291 subjects taking medication for dyslipidemia and/or diabetes and we randomly selected 1090 subjects stratified according to cardiovascular risk for the analysis of resistin plasma levels. Presence of the metabolic syndrome was assessed according to the National Cholesterol Program, Adult Treatment Panel III (NCP-ATPIII) guidelines. These criteria are defined as blood pressure $\geq 130 / 85 \mathrm{mmHg}$, waist circumference $>102 \mathrm{~cm}$ in men and $>88 \mathrm{~cm}$ in women, HDL-cholesterol $<1.03 \mathrm{mmol} / \mathrm{l}$ in men and $<$ $1.29 \mathrm{mmol} / \mathrm{l}$ in women, triglycerides $\geq 1.69 \mathrm{mmol} / \mathrm{l}$, and fasting plasma glucose $\geq 6.1 \mathrm{mmol} / \mathrm{l}$. Obesity was defined as BMI $>30 \mathrm{~kg} / \mathrm{m}^{2}$ and diabetes as fasting glucose $>7 \mathrm{mmol} / \mathrm{l}$.

\section{Determination of plasma resistin levels}

Resistin was measured using a commercially available sandwich ELISA kit (MBL International Corporation, Woburn, MA, USA) within the range of 16$20000 \mathrm{pg} / \mathrm{ml}$, according to the manufacturer's instructions. Plasma samples were diluted 1:5 with PBS. The inter-assay variability was $11 \pm 3 \%$ and the intra-assay variability was $5 \pm 1 \%$. For this analysis, an aliquot of plasma kept at $-80{ }^{\circ} \mathrm{C}$ was thawed for the first time and processed.

\section{Statistical analysis}

Data were analyzed using the program SPSS 11.0 for Windows (Chicago, IL, USA). Bivariate analysis was performed to determine the correlation between plasma resistin levels and the other continuous variables. Differences between groups were calculated using the independent samples $t$-test. Multiple stepwise regression analysis was performed with age-adjusted plasma resistin levels as the dependent variables, and by entering the independent variable with the highest partial correlation coefficient at each step, with a $F$-value probability for inclusion of 0.05 and 0.01 for removal. Group differences or correlations with $P<0.05$ were considered statistically significant.

\section{Results}

Characteristics of PLIC subjects are shown in Table 1. The population is slightly overweight (BMI 26.5 $\left.4.1 \mathrm{~kg} / \mathrm{m}^{2}\right)$ composed by $58.8 \%$ of women $(29 \%$ premenopausal). Plasma resistin levels (mean (s.D.)) are slightly but significantly higher in men compared with women (4.54 (2.17) ng/ml vs 4.17 (2.48) ng/ml; $P<$ 0.05; Table 1). Of note, plasma resistin levels between pre- and postmenopausal women were not different (data not shown), and therefore all further analyses are presented for all population and according to gender.

As plasma resistin levels were significantly correlated with the age of the subjects (coefficient of correlation $(\rho)=0.06 ; P<0.01)$, the correlation of resistin levels with other metabolic and anthropometric parameters was investigated after correction for age. We observed that plasma resistin levels were positively correlated with triglycerides, waist circumference, waist/hip ratio, systolic blood pressure, and ApoAI/ApoB ratio, while they were inversely correlated with HDL and ApoAI levels (Table 2), thus suggesting the correlation of plasma resistin levels with the determinants of the metabolic syndrome. This was observed mainly in women where plasma resistin levels directly correlated with triglycerides and systolic blood pressure, and inversely correlated with HDL-C and ApoAI levels (Table 2); in men, only triglyceride levels correlated with plasma resistin levels. We can not exclude that the correlation with waist circumference, waist/hip ratio, and ApoB/ApoAI is the result of sample grouping. Finally, no correlation of resistin plasma level with insulin and HOMA was observed in agreement with previous findings (29). We performed multiple regression analysis including all the parameters in the statistical model that resulted to be significantly correlated to plasma resistin levels (SBP, waist circumference, waist/hip ratio, HDL-C, triglycerides, ApoAI levels, and ApoB/ApoAI ratio) and we observed that only HDL-C and SBP were independent predictors of plasma resistin levels (Table 3); the ANOVA inflation factors excluded multicollinearity for these variables. When this analysis was performed according to gender, we observed that HDL in women and SBP in men remained the independent predictors of plasma resistin levels (Table 3). Next, we compared subjects with and without the 
Table 1 Clinical and anthropometric parameters of progressione lesione intimale carotidea subjects.

\begin{tabular}{|c|c|c|c|}
\hline & $\begin{array}{c}\text { All }(n=1090) \\
\text { mean (S.D.) }\end{array}$ & $\begin{array}{c}\text { Men }(n=449) ; 41.2 \% \\
\text { mean (s.D.) }\end{array}$ & $\begin{array}{c}\text { Women }(n=641) ; 58.8 \% \\
\text { mean (S.D.) }\end{array}$ \\
\hline Age, years (18-82 years) & $54.4(11.5)$ & $54.6(11.9)$ & $54.3(11.2)$ \\
\hline Total cholesterol $(\mathrm{mmol} / \mathrm{l})$ & $5.8(1.0)$ & $5.7(1.0)$ & $5.8(1.0)^{*}$ \\
\hline LDL cholesterol $(\mathrm{mmol} / \mathrm{l})$ & $3.8(0.9)$ & $3.8(0.9)$ & $3.8(0.9)$ \\
\hline HDL cholesterol ( $\mathrm{mmol} / \mathrm{l})$ & $1.4(0.4)$ & $1.3(0.3)$ & $1.5(0.4)^{*}$ \\
\hline Triglycerides $(\mathrm{mmol} / \mathrm{l})$ & $1.2(0.7)$ & $1.4(0.8)$ & $1.1(0.6)^{*}$ \\
\hline Fasting glucose $(\mathrm{mmol} / \mathrm{l})$ & $5.1(1.0)$ & $5.3(1.0)$ & $4.9(0.9)^{*}$ \\
\hline Resistin (ng/ml) & $4.3(2.4)$ & $4.5(2.2)$ & $4.2(2.5)^{\star}$ \\
\hline $\operatorname{BMI}\left(\mathrm{kg} / \mathrm{m}^{2}\right)$ & $26.5(4.1)$ & $27.0(3.2)$ & $26.1(4.6)^{*}$ \\
\hline Waist circumference $(\mathrm{cm})$ & $89.9(11.7)$ & $96.1(8.5)$ & $85.8(11.8)^{\star}$ \\
\hline Hip circumference $(\mathrm{cm})$ & $103.9(8.4)$ & $104.3(5.9)$ & $103.7(9.7)$ \\
\hline Waist/hip ratio & $0.86(0.08)$ & $0.92(0.06)$ & $0.82(0.06)^{*}$ \\
\hline Systolic blood pressure (mmHg) & $132.7(17.3)$ & $135.8(15.7)$ & $130.5(18.1)^{*}$ \\
\hline Diastolic blood pressure $(\mathrm{mmHg})$ & $82.8(9.2)$ & $84.6(8.3)$ & $81.6(9.6)^{*}$ \\
\hline ApoAl (mg/ml) & $146.9(23.6)$ & $138.7(21.3)$ & $152.6(23.5)^{\star}$ \\
\hline ApoB $(\mathrm{mg} / \mathrm{ml})$ & $114.4(26.2)$ & $115.9(26.5)$ & $113.3(26.0)$ \\
\hline ApoB/ApoAl & $0.80(0.22)$ & $0.85(0.25)$ & $0.76(0.22)^{*}$ \\
\hline IMT (mm; intima-media thickness) & $0.65(0.15)$ & $0.66(0.16)$ & $0.64(0.15)^{\star}$ \\
\hline RCV (\%; risk of coefficient of variation events) & $9.6(7.7)$ & $13.8(8.7)$ & $6.6(5.3)^{*}$ \\
\hline Obesity (\%) & 21.5 & 20.5 & 22.5 \\
\hline Diabetes (\%) & 3.7 & 5.3 & $2.3^{*}$ \\
\hline
\end{tabular}

${ }^{*} P>0.05$ vs men.

metabolic syndrome and we observed that plasma resistin levels were significantly increased $(+17 \%)$ in the presence of the metabolic syndrome (4.85 (2.30) ng/ $\mathrm{ml}$ vs 4.15 (2.24) ng/ml; $P<0.01$; Fig. $1 \mathrm{~A})$. This is true mainly for women where plasma resistin levels were 4.90 $(0.24) \mathrm{ng} / \mathrm{ml}$ vs $3.90(0.11) \mathrm{ng} / \mathrm{ml}(+25 \%)(P<0.01)$, while in men the difference $(4.76(0.28) \mathrm{ng} / \mathrm{ml}$ vs 4.50 (0.11) ng/ml; $(+5.7 \%), P=0.39)$ did not reach the statistical significance. When subjects were stratified according to the presence of increasing number determinants of the metabolic syndrome, plasma resistin levels significantly increase with the increasing presence of the metabolic syndrome determinants (Fig. 1B). When we investigated plasma resistin levels in obese and diabetic subjects, there were no statistically significant differences compared to control $(4.32(0.08) \mathrm{ng} / \mathrm{ml}$ vs $4.31(0.15) \mathrm{ng} / \mathrm{ml}, P=0.92$ and $4.64(0.30) \mathrm{ng} / \mathrm{ml} \mathrm{vs}$ $4.30(0.07) \mathrm{ng} / \mathrm{ml}, P=0.29$ respectively).

Of note, 2-year IMT progression correlated with plasma resistin levels, but this correlation did not reach the statistical significance $(P=0.07$; Table 2$)$. Finally, plasma resistin levels were significantly correlated with cardiovascular risk calculated according to the Framingham algorithm $(P<0.01$; Table 2 and Fig. 2$)$.

Table 2 Spearman correlation of age-adjusted plasma resistin levels with metabolic and blood lipid variables in progressione lesione intimale carotidea subjects.

\begin{tabular}{|c|c|c|c|c|c|c|}
\hline & \multicolumn{2}{|c|}{ All } & \multicolumn{2}{|c|}{ Men } & \multicolumn{2}{|c|}{ Women } \\
\hline & $\rho$ & $P$ & $\rho$ & $P$ & $\rho$ & $P$ \\
\hline Total cholesterol & -0.04 & 0.17 & -0.06 & 0.23 & -0.03 & 0.50 \\
\hline LDL cholesterol & -0.03 & 0.36 & -0.07 & 0.11 & 0.00 & 0.91 \\
\hline HDL cholesterol & -0.14 & $<0.001$ & -0.06 & 0.23 & -0.15 & $<0.001$ \\
\hline Triglycerides & 0.14 & $<0.001$ & 0.12 & 0.008 & 0.12 & 0.002 \\
\hline Glucose & 0.03 & 0.36 & -0.00 & 0.93 & 0.00 & 0.88 \\
\hline BMI & 0.02 & 0.57 & 0.01 & 0.90 & 0.00 & 0.90 \\
\hline Waist circumference & 0.10 & 0.002 & 0.04 & 0.38 & 0.04 & 0.31 \\
\hline Hip circumference & 0.02 & 0.51 & 0.00 & 0.98 & 0.02 & 0.62 \\
\hline Waist/hip ratio & 0.12 & $<0.001$ & 0.07 & 0.15 & 0.04 & 0.32 \\
\hline Systolic blood pressure & 0.09 & 0.002 & 0.06 & 0.20 & 0.08 & 0.038 \\
\hline Diastolic blood pressure & 0.04 & 0.15 & -0.02 & 0.73 & 0.05 & 0.22 \\
\hline ApoAl & -0.09 & 0.001 & 0.01 & 0.79 & -0.13 & 0.005 \\
\hline ApoB & 0.03 & 0.30 & 0.01 & 0.85 & 0.03 & 0.45 \\
\hline ApoB/ApoAl & 0.07 & 0.050 & -0.01 & 0.85 & 0.08 & 0.06 \\
\hline $\mathrm{IMT}_{0}$ & 0.01 & 0.79 & 0.04 & 0.40 & -0.03 & 0.43 \\
\hline$\Delta \mathrm{IMT}$ & 0.06 & 0.07 & 0.05 & 0.37 & 0.07 & 0.11 \\
\hline RCV & 0.18 & $<0.001$ & 0.11 & 0.016 & 0.16 & $<0.001$ \\
\hline
\end{tabular}

Spearman correlation coefficient is shown. 
Table 3 Overall multiple regression analysis between age-adjusted plasma resistin levels (dependent variable) and systolic blood pressure, waist circumference, waist/hip ratio, HDL-C, triglycerides, ApoAI levels, and ApoB/ApoAl ratio (independent variables) in all subjects and according to gender.

\begin{tabular}{|c|c|c|c|c|c|c|}
\hline \multirow[b]{2}{*}{ Independent variable } & \multicolumn{2}{|c|}{ All } & \multicolumn{2}{|c|}{ Men } & \multicolumn{2}{|c|}{ Women } \\
\hline & $\beta$ & $P$ & $\beta$ & $P$ & $\beta$ & $P$ \\
\hline SBP & 0.094 & $<0.001$ & 0.129 & 0.043 & 0.065 & 0.204 \\
\hline Waist circumference & 0.025 & 0.552 & 0.057 & 0.381 & -0.040 & 0.455 \\
\hline Waist/hip ratio & 0.066 & 0.119 & 0.044 & 0.495 & 0.001 & 0.981 \\
\hline HDL-C & -0.151 & $<0.001$ & -0.103 & 0.109 & -0.129 & $<0.001$ \\
\hline Triglycerides & 0.070 & 0.110 & 0.103 & 0.108 & 0.059 & 0.294 \\
\hline ApoAl & 0.082 & 0.217 & -0.021 & 0.745 & 0.047 & 0.204 \\
\hline ApoB/ApoAl & -0.067 & 0.195 & -0.037 & 0.567 & -0.015 & 0.825 \\
\hline
\end{tabular}

\section{Discussion}

The major finding of this study is that plasma resistin levels correlate with triglycerides, HDL-C, ApoAI, systolic blood pressure, waist/hip ratio, ApoB/ApoAI ratio, and the cardiovascular risk in the general population. Furthermore, plasma resistin levels increase with the number of determinants of the metabolic syndrome. Of note, plasma resistin levels are not increased in obese or diabetic subjects, but we cannot exclude that as we lack the power to detect these differences.

Resistin is a protein involved in glucose homeostasis, lipid metabolism, and insulin action and in mice it is expressed mainly in adipose tissue $(11,30)$, while in humans both adipocyte and inflammatory cells contribute to its production $(29,31,32)$. Reilly et al. demonstrated that plasma resistin levels are associated with inflammatory markers in a large, non-diabetic cohort as well as in type 2 diabetes, and also that resistin is also associated with coronary artery calcification (29). Despite these findings, the role of resistin in the metabolic syndrome is controversial. Some papers reported that in humans plasma resistin levels correlate with obesity, insulin resistance, and type 2 diabetes (4, 33-35), while other authors failed to observe any correlation of plasma resistin levels with either metabolic or lipid markers (29), and no significant difference was observed in plasma resistin levels in subjects with the metabolic syndrome compared to controls (21, 36-40). Different explanations could account for these discrepancies, including the use of different assay methods, the low number of patients enrolled in the different studies, and the definition used to select patients with the metabolic syndrome. To minimize these biases, we investigated the relation of plasma resistin levels in a cohort encompassing more than 1000 of subjects where the presence of the metabolic syndrome was defined according to the ATPIII panel. Plasma resistin levels were correlated with HDL-C, triglycerides, waist circumference, and systolic blood pressure; furthermore, subjects with the metabolic syndrome showed higher plasma resistin levels compared with controls. This is in contrast with Utzschneider et al. that failed to find any correlation of plasma resistin levels with the metabolic syndrome (21). One explanation could be that their analysis was restricted to 177 subjects including only 20 subjects with the metabolic syndrome, thus may be limiting the power of the analysis; alternatively, different genetic background of the participants could account for the differences observed. Of note, when we stratified the data according to gender, we found that plasma resistin levels were significantly increased only in women with the metabolic syndrome, while no
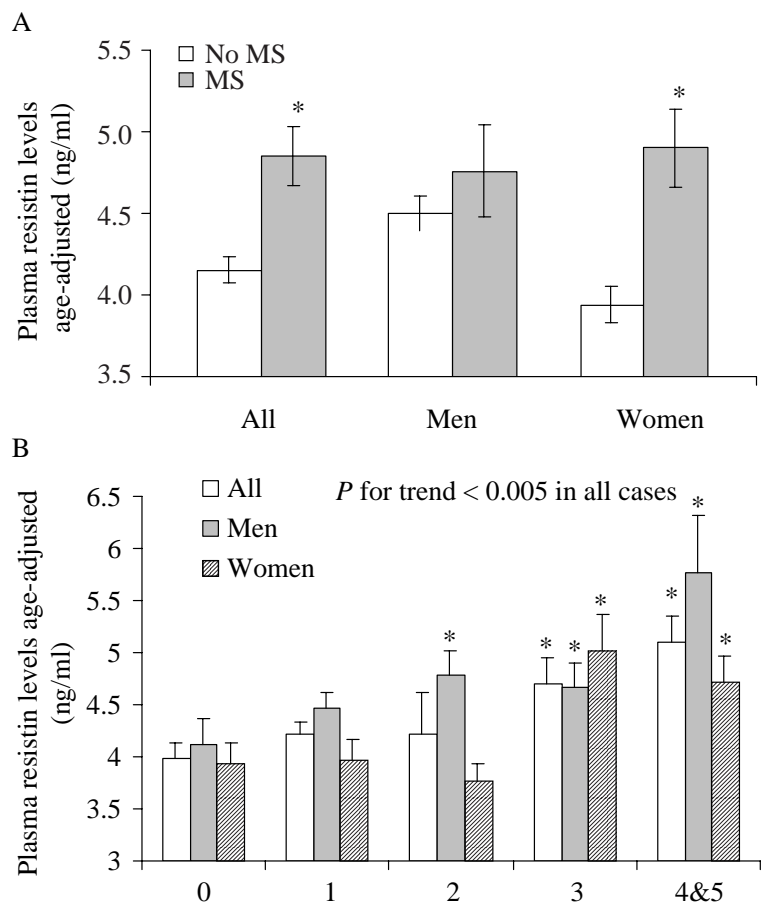

Figure 1 (A) Comparison of age-adjusted plasma resistin levels in control subjects versus subjects with the metabolic syndrome. Data are presented for all population according to gender and are expressed as mean $(\mathrm{ng} / \mathrm{ml}) \pm$ standard error. ${ }^{*} P<0.05$ subjects with the metabolic syndrome versus control group (values for subjects with and without the metabolic syndrome are indicated with shaded or open bars respectively). (B) Evaluation of age-adjusted plasma resistin levels according to the number of determinants of the metabolic syndrome (NCP-ATPIII guidelines). Data are expressed as mean $(\mathrm{ng} / \mathrm{ml}) \pm$ standard error. ${ }^{*} P<0.05$ versus control group without any determinant of the metabolic syndrome (0). 




Figure 2 In PLIC, age-adjusted plasma resistin levels are correlated with cardiovascular risk calculated according to the Framingham algorithm (RCV; Spearman $R=0.185, P<0.001$ ). Linear regression line is shown.

significant difference was observed in men with and without the metabolic syndrome. Similarly, the relation of plasma resistin levels with HDL-C, triglycerides, ApoAI levels, and SBP remained significant in women, while in men only a correlation between plasma resistin levels and triglycerides was observed. A different role of resistin according to gender was also observed by other authors. Pischon et al. demonstrated that plasma resistin levels were significantly associated with the presence of coronary heart disease only in women (41) and Chenn et al. (42) showed that associations between plasma resistin levels with metabolic and anthropometric parameters were different in men compared with women. When we performed multiple regression analysis using age-adjusted plasma resistin levels as the dependent variable, HDL-C level resulted to be an independent predictor of resistin in women, while only SBP was the independent predictor of resistin in men; however, we can not exclude that resistin per se may affect HDL and SBP. We could only speculate that the gender-specific effect of resistin could depend on different adipose tissue depots that are responsible for its production in male or female.

Finally, we observed a relation between plasma resistin levels and cardiovascular risk. Although in this work we have not addressed whether resistin levels correlate with markers on the inflammatory response, Reilly et al. found a strong positive association with plasma levels of interleukin-6 and tumor necrosis factor- $\alpha$ in healthy subjects, who had a family history of premature coronary artery disease (29), while Kunnari et al. showed a positive correlation with leukocytes and high-sensitive C-reactive protein (43). All these data suggest that in humans resistin could be related both to the metabolic and to the cardiovascular inflammatory state. Alternatively, as metabolic syndrome by itself is associated with inflammation, there might be the possibility that resistin is rather associated with inflammation markers that would appear at different stages of metabolic syndrome development, and its correlation with other metabolic and anthropometric parameters like glucose, blood lipids, and BMI is just a secondary effect. Indeed, pharmacological approaches with TZD reduce resistin levels $(44,45)$, although not all reports are consistent with these findings (46).

In conclusion, we found that plasma resistin levels are associated with several metabolic and anthropometric parameters, and with cardiovascular risk in the general population. Furthermore, plasma resistin levels are significantly increased in women with the metabolic syndrome.

\section{References}

1 Wolf G. Insulin resistance and obesity: resistin, a hormone secreted by adipose tissue. Nutrition Reviews 200462 389-394.

2 Holcomb IN, Kabakoff RC, Chan B, Baker TW, Gurney A, Henzel W, Nelson C, Lowman HB, Wright BD, Skelton NJ, Frantz GD, Tumas DB, Peale FV Jr, Shelton DL \& Hebert CC. FIZZ1, a novel cysteine-rich secreted protein associated with pulmonary inflammation, defines a new gene family. EMBO Journal 200019 4046-4055.

3 Kim KH, Lee K, Moon YS \& Sul HS. A cysteine-rich adipose tissuespecific secretory factor inhibits adipocyte differentiation. Journal of Biological Chemistry 2001276 11252-11256.

4 Steppan CM, Bailey ST, Bhat S, Brown EJ, Banerjee RR, Wright CM, Patel HR, Ahima RS \& Lazar MA. The hormone resistin links obesity to diabetes. Nature $2001409307-312$.

5 Satoh H, Nguyen MT, Miles PD, Imamura T, Usui I \& Olefsky JM. Adenovirus-mediated chronic 'hyper-resistinemia' leads to in vivo insulin resistance in normal rats. Journal of Clinical Investigation $2004114224-231$.

6 Steppan CM \& Lazar MA. The current biology of resistin. Journal of Internal Medicine 2004255 439-447.

7 Banerjee RR, Rangwala SM, Shapiro JS, Rich AS, Rhoades B, Qi Y, Wang J, Rajala MW, Pocai A, Scherer PE, Steppan CM, Ahima RS, Obici S, Rossetti L \& Lazar MA. Regulation of fasted blood glucose by resistin. Science 2004303 1195-1198.

8 Rangwala SM, Rich AS, Rhoades B, Shapiro JS, Obici S, Rossetti L \& Lazar MA. Abnormal glucose homeostasis due to chronic hyperresistinemia. Diabetes 200453 1937-1941.

9 Nogueiras R, Gallego R, Gualillo O, Caminos JE, Garcia-Caballero T, Casanueva FF \& Dieguez C. Resistin is expressed in different rat tissues and is regulated in a tissue- and gender-specific manner. FEBS Letters $2003 \mathbf{5 4 8} 21-27$

10 Sato N, Kobayashi K, Inoguchi T, Sonoda N, Imamura M, Sekiguchi N, Nakashima N \& Nawata H. Adenovirus-mediated high expression of resistin causes dyslipidemia in mice. Endocrinology $2005146273-279$.

11 Rajala MW, Obici S, Scherer PE \& Rossetti L. Adipose-derived resistin and gut-derived resistin-like molecule-beta selectively impair insulin action on glucose production. Journal of Clinical Investigation $2003111225-230$.

12 Muse ED, Obici S, Bhanot S, Monia BP, McKay RA, Rajala MW, Scherer PE \& Rossetti L. Role of resistin in diet-induced hepatic insulin resistance. Journal of Clinical Investigation $2004 \mathbf{1 1 4}$ 232-239.

13 Juan CC, Au LC, Fang VS, Kang SF, Ko YH, Kuo SF, Hsu YP, Kwok CF \& Ho LT. Suppressed gene expression of adipocyte resistin 
in an insulin-resistant rat model probably by elevated free fatty acids. Biochemical and Biophysical Research Communications 2001 289 1328-1333.

14 Le Lay S, Boucher J, Rey A, Castan-Laurell I, Krief S, Ferre P, Valet P \& Dugail I. Decreased resistin expression in mice with different sensitivities to a high-fat diet. Biochemical and Biophysical Research Communications 2001289 564-567.

15 Way JM, Gorgun CZ, Tong Q, Uysal KT, Brown KK, Harrington WW, Oliver WR Jr, Willson TM, Kliewer SA \& Hotamisligil GS. Adipose tissue resistin expression is severely suppressed in obesity and stimulated by peroxisome proliferatoractivated receptor gamma agonists. Journal of Biological Chemistry $200127625651-25653$.

16 Ukkola O. Resistin - a mediator of obesity-associated insulin resistance or an innocent bystander? European Journal of Endocrinology 2002147 571-574.

17 Pagano C, Marin O, Calcagno A, Schiappelli P, Pilon C, Milan G, Bertelli M, Fanin E, Andrighetto G, Federspil G \& Vettor R. Increased serum resistin in adults with prader-willi syndrome is related to obesity and not to insulin resistance. Journal of Clinical Endocrinology and Metabolism 200590 4335-4340.

18 Matsuda M, Kawasaki F, Yamada K, Kanda Y, Saito M, Eto M, Matsuki M \& Kaku K. Impact of adiposity and plasma adipocytokines on diabetic angiopathies in Japanese type 2 diabetic subjects. Diabetic Medicine 200421 881-888.

19 Burnett MS, Devaney JM, Adenika RJ, Lindsay R \& Howard BV. Cross-sectional associations of resistin, coronary heart disease, and insulin resistance. Journal of Clinical Endocrinology and Metabolism 200691 64-68.

20 Farvid MS, Ng TW, Chan DC, Barrett PH \& Watts GF. Association of adiponectin and resistin with adipose tissue compartments, insulin resistance and dyslipidaemia. Diabetes, Obesity and Metabolism 20057 406-413.

21 Utzschneider KM, Carr DB, Tong J, Wallace TM, Hull RL, Zraika S, Xiao Q, Mistry JS, Retzlaff BM, Knopp RH \& Kahn SE. Resistin is not associated with insulin sensitivity or the metabolic syndrome in humans. Diabetologia 200548 2330-2333.

22 Filippidis G, Liakopoulos V, Mertens PR, Kiropoulos T, Stakias N, Verikouki C, Patsidis E, Koukoulis G \& Stefanidis I. Resistin serum levels are increased but not correlated with insulin resistance in chronic hemodialysis patients. Blood Purification 200523 421-428.

23 Zou CC, Liang L, Hong F, Fu JF \& Zhao ZY. Serum adiponectin, resistin levels and non-alcoholic fatty liver disease in obese children. Endocrine Journal 200552 519-524.

24 Savage DB, Sewter CP, Klenk ES, Segal DG, Vidal-Puig A, Considine RV \& O'Rahilly S. Resistin/Fizz3 expression in relation to obesity and peroxisome proliferator-activated receptor-gamma action in humans. Diabetes 200150 2199-2202.

25 Lakka HM, Laaksonen DE, Lakka TA, Niskanen LK, Kumpusalo E, Tuomilehto J \& Salonen JT. The metabolic syndrome and total and cardiovascular disease mortality in middle-aged men. Journal of the American Medical Association 2002288 2709-2716.

26 Ninomiya JK, L'Italien G, Criqui MH, Whyte JL, Gamst A \& Chen RS. Association of the metabolic syndrome with history of myocardial infarction and stroke in the Third National Health and Nutrition Examination Survey. Circulation 2004109 42-46.

27 Norata GD, Garlaschelli K, Ongari M, Raselli S, Grigore L, Benvenuto F, Maggi FM \& Catapano AL. Effect of the Toll-like receptor 4 (TLR-4) variants on intima-media thickness and monocyte-derived macrophage response to LPS. Journal of Internal Medicine 2005258 21-27.

28 Norata GD, Garlaschelli K, Ongari M, Raselli S, Grigore L \& Catapano AL. Effects of fractalkine receptor variants on common carotid artery intima-media thickness. Stroke 200637 1558-1561.

29 Reilly MP, Lehrke M, Wolfe ML, Rohatgi A, Lazar MA \& Rader DJ. Resistin is an inflammatory marker of atherosclerosis in humans. Circulation $2005111932-939$.

30 Rajala MW \& Scherer PE. Minireview: the adipocyte - at the crossroads of energy homeostasis, inflammation, and atherosclerosis. Endocrinology 2003144 3765-3773.
31 Yang RZ, Huang Q, Xu A, McLenithan JC, Eisen JA, Shuldiner AR Alkan S \& Gong DW. Comparative studies of resistin expression and phylogenomics in human and mouse. Biochemical and Biophysical Research Communications 2003310 927-935.

32 Kaser S, Kaser A, Sandhofer A, Ebenbichler CF, Tilg H \& Patsch JR. Resistin messenger-RNA expression is increased by proinflammatory cytokines in vitro. Biochemical and Biophysical Research Communications 2003309 286-290.

33 Azuma K, Katsukawa F, Oguchi S, Murata M, Yamazaki H, Shimada A \& Saruta T. Correlation between serum resistin level and adiposity in obese individuals. Obesity Research 200311 997-1001.

34 Silha JV, Krsek M, Skrha JV, Sucharda P, Nyomba BL \& Murphy LJ. Plasma resistin, adiponectin and leptin levels in lean and obese subjects: correlations with insulin resistance. European Journal of Endocrinology $2003149331-335$.

35 Steppan CM \& Lazar MA. Resistin and obesity-associated insulin resistance. Trends in Endocrinology and Metabolism 200213 18-23.

36 Nagaev I \& Smith U. Insulin resistance and type 2 diabetes are not related to resistin expression in human fat cells or skeletal muscle. Biochemical and Biophysical Research Communications $20012 \mathbf{2 8 5}$ 561-564.

37 Janke J, Engeli S, Gorzelniak K, Luft FC \& Sharma AM. Resistin gene expression in human adipocytes is not related to insulin resistance. Obesity Research 200210 1-5.

38 Lee JH, Chan JL, Yiannakouris N, Kontogianni M, Estrada E, Seip R, Orlova C \& Mantzoros CS. Circulating resistin levels are not associated with obesity or insulin resistance in humans and are not regulated by fasting or leptin administration: cross-sectional and interventional studies in normal, insulin-resistant, and diabetic subjects. Journal of Clinical Endocrinology and Metabolism $2003 \mathbf{8 8} 4848-4856$.

39 Pfutzner A, Langenfeld M, Kunt T, Lobig M \& Forst T. Evaluation of human resistin assays with serum from patients with type 2 diabetes and different degrees of insulin resistance. Clinical Laboratory $2003 \mathbf{4 9} 571-576$.

40 Iqbal N, Seshadri P, Stern L, Loh J, Kundu S, Jafar T \& Samaha FF. Serum resistin is not associated with obesity or insulin resistance in humans. European Review for Medical and Pharmacological Sciences 20059 161-165.

41 Pischon T, Bamberger CM, Kratzsch J, Zyriax BC, Algenstaedt P, Boeing $\mathrm{H} \&$ Windler E. Association of plasma resistin levels with coronary heart disease in women. Obesity Research 200513 1764-1771.

42 Chen CC, Li TC, Li CI, Liu CS, Wang HJ \& Lin CC. Serum resistin level among healthy subjects: relationship to anthropometric and metabolic parameters. Metabolism $2005 \mathbf{5 4} 471-475$.

43 Kunnari A, Ukkola O, Paivansalo M \& Kesaniemi YA. High plasma resistin level is associated with enhanced hsCRP and leucocytes. Journal of Clinical Endocrinology and Metabolism $2006 \mathbf{9 1}$ 2755-2760.

44 Szapary PO, Bloedon LT, Samaha FF, Duffy D, Wolfe ML, Soffer D, Reilly MP, Chittams J \& Rader DJ. Effects of pioglitazone on lipoproteins, inflammatory markers, and adipokines in nondiabetic patients with metabolic syndrome. Arteriosclerosis, Thrombosis, and Vascular Biology 200626 182-188.

45 Samaha FF, Szapary PO, Iqbal N, Williams MM, Bloedon LT, Kochar A, Wolfe ML \& Rader DJ. Effects of rosiglitazone on lipids, adipokines, and inflammatory markers in nondiabetic patients with low high-density lipoprotein cholesterol and metabolic syndrome. Arteriosclerosis, Thrombosis, and Vascular Biology 2006 26 624-630.

46 Kim SG, Ryu OH, Kim HY, Lee KW, Seo JA, Kim NH, Choi KM, Lee J, Baik SH \& Choi DS. Effect of rosiglitazone on plasma adiponectin levels and arterial stiffness in subjects with prediabetes or nondiabetic metabolic syndrome. European Journal of Endocrinology 2006154 433-440.

Received 22 September 2006

Accepted 30 November 2006 